\title{
Pathogenicity of Root - Knot Nematode Meloidogyne javanica on Cucumber Plants at Different Inoculum levels Under Greenhouse Conditions
}

\author{
Sulaiman Naif Ami*, Shireen Ghaeib Ali Shingaly \\ Department of Plant Protection, College of Agricultural Engineering Sciences, University of Duhok, Duhok, Kurdistan Region - \\ Iraq (sulaiman.ami@uod.ac,shireenghaeeb@yahoo.com) \\ *Correspondence: sulaiman.ami@uod.ac
}

\begin{abstract}
Root-knot nematodes are dangerous and economically very important pest of completely cultivated crops in the world, so this study was conducted to test the pathogenicity of root-knot nematode Meloidogyne javanica at different levels of soil infestation by nematode eggs against one of the most common cultivar (hybrid) of cucumber cultivated in Duhok province. Sterilized sandy loam soil was infested with different levels of inoculum of root - knot nematode $M$. javanica included: $0,1000,2000,4000,8000$ and 16000 eggs/pot after 20 days of sowing cucumber seeds cv. Sayff F1 under greenhouses conditions at College of Agricultural Engineering Sciences / Semel, University of Duhok. Results revealed that the growth criteria of cucumber plants (length, fresh and dry weight of roots and shoots) and chlorophyll content of leaves decreased with increasing of inoculum levels of nematode eggs, whereas the infection criteria increased except with level 16000 eggs / pot at which the infection criteria decreased. At the same time nematode reproduction rate decreased with increasing of nematode inoculum levels.
\end{abstract}

Keywords: Pathogenicity, M. javanica, Inoculum Levels, Cucumber

Received: October $25^{\text {th }}, 2020 /$ Accepted: November $26^{\text {th }}, 2020 /$ Online: December $20^{\text {th }}, 2020$

\section{INTRODUCTION}

Root-knot nematodes are dangerous and economically very important pest of completely cultivated crops in the world (Hussain et al., 2011). Species of this nematode are mainly damaging the vegetable crops in tropical and subtropical regions (Mukhtar et al., 2013). The most important species of root-knot nematodes are $M$. javanica, $M$. arenaria, $M$. incognita and $M$. hapla that cause high economic damages in different crops (Khalil, 2013). In a pot experiment Maleita et al., (2012) studied the effect of egg levels (2500, 5000 and 10000 eggs/pot) of $M$. javanica and M. hispanica on tomato, results showed that there was a trend of decreasing in growth criteria (length and weight of roots and shoot) with increasing of initial nematode population levels. The effects of initial population levels $(0$, $0.125,0.25,0.5,1,2,4,8$ and 16 eggs/gm of soil) of M. javanica on cucumber were conducted in greenhouse pots, and it was noted that the fresh weight and shoot length were decreased at 16 eggs of M. javanica /gm of soil, while the number of galls and nematode eggs increased with the increasing of inoculum levels and at the end nematode reproduction rate decreased
(Charegani et al., 2012). On the effect of inoculum levels (0, 500,1000 , and $2000 \mathrm{~J} 2 \mathrm{~s}$ ) of root-knot nematodes on growth of tomato cv. Pectomec, results revealed that increasing the nematode inoculum levels caused increasing in nematode population density and number of galls (Kankam and Adomako, 2014). Maximum galls and egg masses/root system of green gram were recorded in 100 and $1000 \mathrm{~J} 2$ of $M$. javanica $/ \mathrm{kg}$ of soil, which ultimately decreased at 10000 inoculum level as nematode population density increased in the soil with an increasing the inoculum level of nematode (Sumita, 2014). This study was designed to test the pathogenicity of rootknot nematode $M$. javanica at different levels of soil infestation by nematode eggs against one of the most common hybrid cultivar of cucumber cultivated in Duhok province.

\section{MATERIALS AND METHODS}

\section{A. Pathogenicity of root-knot nematode M. javanica on cucumber plants}

Plastic pots with a diameter of $19 \mathrm{~cm}$ and depth of $18 \mathrm{~cm}$ were filled with sterilized sandy 
loam soil (17.63 clay, 18.64 silt and $63.73 \%$ sand) by $3.5 \mathrm{~kg}$ of soil/pot. Five seeds of hybrid cucumber cv. Sayff F1 were planted in each pot as it is the most widespread cultivated hybrids in Duhok province.10 days later thinning process were done to keep 2 plants/pot, then the pots were buried to specific level (plunged) randomly in the soil of one of the greenhouse at College of Agricultural Engineering Sciences in Semel/University of Duhok. The inner lining of the greenhouse was covered with tulle fabric carefully to avoid entry of insects. After 20 days from seed sowing, the seedlings were infested individually with different inoculum levels of root-knot nematode $M$. javanica included: 0, 1000, 2000, 4000, 8000, 16000 eggs/pot by making holes around the plant with a sterilized glass rod, and with a depth of $3 \mathrm{~cm}$ and $2 \mathrm{~cm}$ away from the plant. Nematode eggs inoculum was added to the soil through these holes which covered directly with sterilized soil. Pots were watered as needed and plants were uprooted carefully after 2 months of soil infestation with nematode eggs to calculate the following characters:

a. Plant growth criteria: (1)-Chlorophyll (SPAD) measured by chlorophyll meter (SPAD502/Konica Minolta Sensing, INC. made in Japan). (2) Shoot and root length (cm/plant). (3) Fresh weight of shoot and root (g/plant). (4) Dry weight of root and shoot (g/plant):

b. Calculation of reduction percentage in growth criteria and chlorophyll content of leaves according to the following equation:

$$
\% \text { Reduction }=\text { - } \frac{\text { Control }(\text { non }- \text { infested soil })-\text { Treatment }}{\text { Control }(\text { non }- \text { infested soil })}
$$

c. Infection criteria

(1) The number of root galls/root system of the plant. (2) Root gall severity: Depending on galling index (GI) measure in 0-5 scales and as follow: $(0=0,1=1-2,2=3-10,3=11-30,4=31-100$, $5=$ more than 100 galls /root system (Kumar et al., 2014). (3) Nematode population density in the soil for each pot by the tray method as mentioned by Coyne et al. (2007). 4-Number of egg masses/root system by staining method as described by Stetina and Young, (2006). (5) Nematode population density/root system by staining method (Stetina and Young, 2006) as follow: Cucumber roots were washed with tap water to remove soil. Then, roots were drained on paper towels and cut to $1 \mathrm{~cm}$. Next, roots were stained with red food color according to the method mentioned by Thies et al. (2002). Egg masses and nematode inside the roots were counted using a stereomicroscope. Results were expressed as females per each gram of roots. (6) Number of eggs according to the method mentioned by Coyne et al. (2007). (7) Rate of nematode reproduction according to the following equation:

Final population density $=$ Number of nematodes in soil + Number of nematodes in roots + Number of eggs root system. Rate of nematode reproduction $=$ Final population density of nematode / initial population density of nematode.

\section{B. Experimental Design and Statistical analysis}

This experiment consisted of 6 treatments with 4 replications. Data were analyzed using the SAS program to compare the means of studied characters depending on Duncan's multiple range test, $\mathrm{p} \leq 0.05$ (SAS, 2001).

\section{RESULTS}

\section{A. Effect of different inoculum levels of $M$. javanica eggs on some growth criteria and chlorophyll content of cucumber plants under greenhouse conditions}

Results indicated that infested soil with different inoculum levels of nematode eggs caused a notable reduction in some growth criteria of cucumber plants included fresh, dry weight and length of root and shoot system with chlorophyll content of leaves as compared with the control treatment (Fig. 1). The values of the studied characters were decreased with increasing of inoculum levels starting with $13.25 \mathrm{~g} /$ plant, $3.5 \mathrm{~g} / \mathrm{plant}, 17.25$ $\mathrm{cm} /$ plant, $24.25 \mathrm{gm} /$ plant, $7.5 \mathrm{~g} /$ plant, $56.25 \mathrm{~cm} /$ plant and 30.48 SPAD respectively at the minimum level (1000 eggs/pot) (Table 1), thus, it achieved a reduction by $19.69,16.67,27.37$, 27.61, 18.92, 12.79 and 9.70 (Table 2) and ending with 6.25 gm/plant, $1.5 \mathrm{gm} /$ plant, $3.75 \mathrm{~cm} /$ plant, $5.5 \mathrm{gm} /$ plant, 1.75 $\mathrm{gm} /$ plant, $9 \mathrm{~cm} /$ plant and 25.29 SPAD respectively at the maximum level (16000 eggs/pot) (Table 1) that is, it caused a reduction by $62.12,60,84.21,83.58,81.08,86.05$ and $18.21 \%$ in previous characteristics (Table 2). Results of statistical analysis also showed that the reduction in most growth criteria caused by all the inoculum levels of nematode eggs was significant compared to the control treatment (non-infested soil) except in chlorophyll content at all inoculum levels, dry weight of root system at the level 1000, 2000 and 4000 eggs / pot respectively and dry weight of shoot system at the level 1000 eggs / pot where the reduction was not significant compared to the control treatment.. However, the difference was not significant between inoculum levels in their impact in some growth criteria of cucumber plants. 


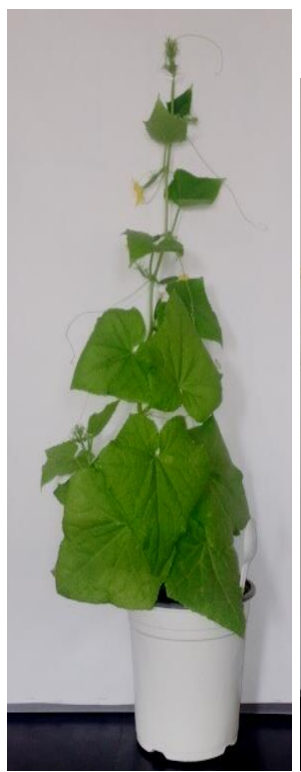

1

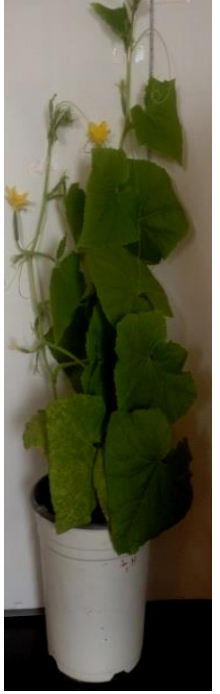

2

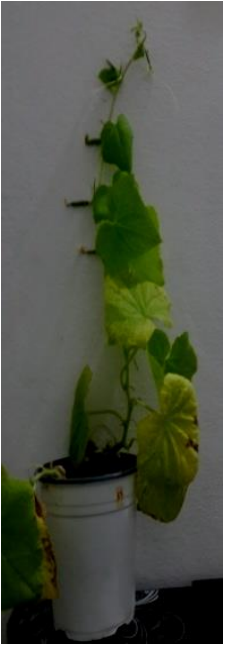

3

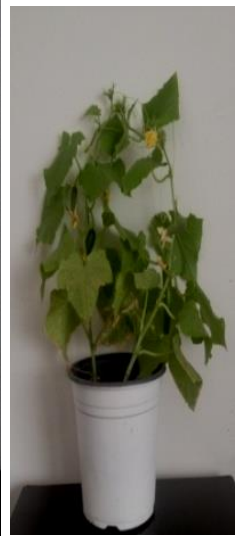

4

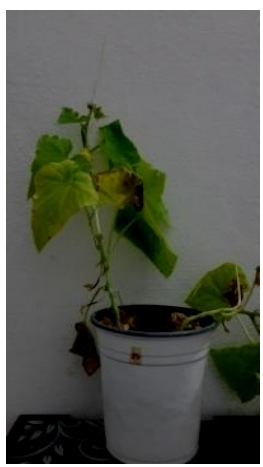

5

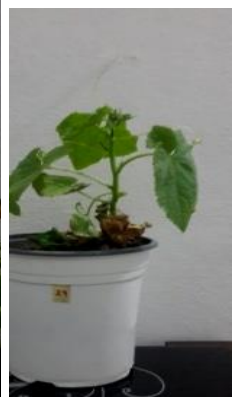

6

Figure 1. Healthy cucumber plants (1) compared to diseased plants (2,3,4,5 and 6) grown in soil infested with 1000, 2000, 4000, 8000, 16000 eggs of M. javanica respectively.

Table 1. Effect of different inoculum levels of $M$. javanica eggs on some growth criteria and chlorophyll content of cucumber plants cv.Saffy F1 under greenhouse conditions.

\begin{tabular}{|c|c|c|c|c|c|c|c|}
\hline \multirow{3}{*}{$\begin{array}{l}\text { Treatments } \\
\text { (eggs/pot) }\end{array}$} & \multicolumn{7}{|c|}{ Growth Criteria } \\
\hline & \multicolumn{3}{|c|}{ Root system } & \multicolumn{4}{|c|}{ Shoot system } \\
\hline & $\begin{array}{c}\text { F.W. } \\
\text { (gm/plant) }\end{array}$ & $\begin{array}{c}\text { D.W. } \\
\text { (gm/plant) }\end{array}$ & $\begin{array}{c}\text { R.L. } \\
\text { (cm/plant) }\end{array}$ & $\begin{array}{c}\text { F.W. } \\
\text { (gm/plant) }\end{array}$ & $\begin{array}{c}\text { D.W. } \\
\text { (gm/plant) }\end{array}$ & $\begin{array}{c}\text { S.L. } \\
\text { (cm/plant) }\end{array}$ & $\begin{array}{c}\text { Chl } \\
\text { (SPAD) }\end{array}$ \\
\hline 1000 & $13.25 \mathrm{~b}$ & $3.5 \mathrm{ab}$ & $17.25 \mathrm{~b}$ & $24.25 \mathrm{~b}$ & $7.5 \mathrm{a}$ & $56.25 \mathrm{~b}$ & $30.48 \mathrm{a}$ \\
\hline 2000 & $11.75 \mathrm{~b}$ & $3 a b$ & $15.5 \mathrm{~b}$ & $21.5 \mathrm{~b}$ & $4.75 \mathrm{~b}$ & $34.5 \mathrm{c}$ & $30.13 \mathrm{a}$ \\
\hline 4000 & $9.5 \mathrm{c}$ & $2.5 \mathrm{abc}$ & $10.75 \mathrm{c}$ & $16.75 \mathrm{c}$ & $4.25 \mathrm{bc}$ & $25.75 \mathrm{~d}$ & $30.09 \mathrm{a}$ \\
\hline 8000 & $7.75 \mathrm{~cd}$ & $2.25 \mathrm{bc}$ & $7.5 \mathrm{~d}$ & $8.25 \mathrm{~d}$ & $2.5 \mathrm{~cd}$ & $15.75 \mathrm{e}$ & $26.73 \mathrm{a}$ \\
\hline 16000 & $6.25 \mathrm{~d}$ & $1.5 \mathrm{c}$ & $3.75 \mathrm{e}$ & $5.5 \mathrm{~d}$ & $1.75 \mathrm{~d}$ & $9 \mathrm{f}$ & $25.29 \mathrm{a}$ \\
\hline $\begin{array}{l}\text { Control (non } \\
\text { infested soil) }\end{array}$ & $16.5 \mathrm{a}$ & $3.75 \mathrm{a}$ & $23.75 \mathrm{a}$ & $33.5 \mathrm{a}$ & $9.25 \mathrm{a}$ & $64.5 \mathrm{a}$ & $30.923 \mathrm{a}$ \\
\hline
\end{tabular}

- Means with different letter (s) are differ significantly according to Dunca,s Multiple Range test $(\mathrm{P} \leq 0.05)$-Each number is a mean of 4 replications.

- Treatments (inoculum levels), F.W. = Fresh weight, D.W. = Dry weight, R.L. = Root length, S.L. $=$ Shoot length, Chl. $=$ Chlorophyll.

\section{B. Effect of different inoculum levels of M. javanica eggs on some infection criteria in cucumber plants}

Results of statistical analysis revealed that the inoculum levels of nematode eggs affected significantly on the infection criteria included, number of: root galls, egg masses, (Fig. 2), eggs and nematode stages in cucumber roots as well as nematode population density in the soil and final nematode population density in addition to nematode reproduction rate while the effect was not significant on the root gall index because it depends mainly on a range of a specific number of the root galls (Table 3). The lowest values of the infection criteria were recorded by the last level of infestation (16000 eggs/pot) except number of nematode /root system where it excelled on the first level (1000 eggs/pot) after which values of infection criteria began to increase and thus the highest values were reported by the level 8000 eggs/pot, namely: 241 galls/root system, 140 egg mass/root system, 65362.5 eggs / root system,7727 nematode stages / root system, $142362.5 \mathrm{~J} 2$ / pot, 215452 nematode stages / pot including soil and cucumber root system and 26.93 as a rate of nematode reproduction. 
Table 2: The percentage of reduction in some growth criteria and chlorophyll content of cucumber plants as affected by different inoculum levels of root- knot nematode M. javanica eggs.

\begin{tabular}{|c|c|c|c|c|c|c|c|}
\hline \multirow{2}{*}{$\begin{array}{c}\text { Treatments } \\
\text { (eggs/pot) }\end{array}$} & \multicolumn{5}{|c|}{ Percentage of reduction in growth criteria \% } \\
\cline { 2 - 8 } & $\begin{array}{c}\text { F.W. } \\
\text { (gm / plant) }\end{array}$ & $\begin{array}{c}\text { D.W. } \\
\text { (gm/plant) }\end{array}$ & $\begin{array}{c}\text { R.L. } \\
\text { (cm/plant) }\end{array}$ & $\begin{array}{c}\text { F.W. } \\
(\mathrm{gm} / \text { plant })\end{array}$ & $\begin{array}{c}\text { D.W. } \\
(\mathrm{gm} / \mathrm{plant})\end{array}$ & $\begin{array}{c}\text { S.L. } \\
(\mathrm{cm} / \mathrm{plant})\end{array}$ & $\begin{array}{c}\text { Chl } \\
(\mathrm{SPAD})\end{array}$ \\
\hline 1000 & 19.69 & 16.67 & 27.37 & 27.61 & 18.92 & 12.79 & 9.70 \\
\hline 2000 & 28.79 & 23.33 & 34.74 & 35.82 & 48.65 & 46.51 & 9.59 \\
\hline 4000 & 42.42 & 36.67 & 54.74 & 49.99 & 54.05 & 60.08 & 15.77 \\
\hline 8000 & 53.03 & 40 & 68.42 & 75.37 & 72.97 & 75.58 & 13.55 \\
\hline 16000 & 62.12 & 60 & 84.21 & 83.58 & 81.08 & 86.05 & 18.21 \\
\hline
\end{tabular}
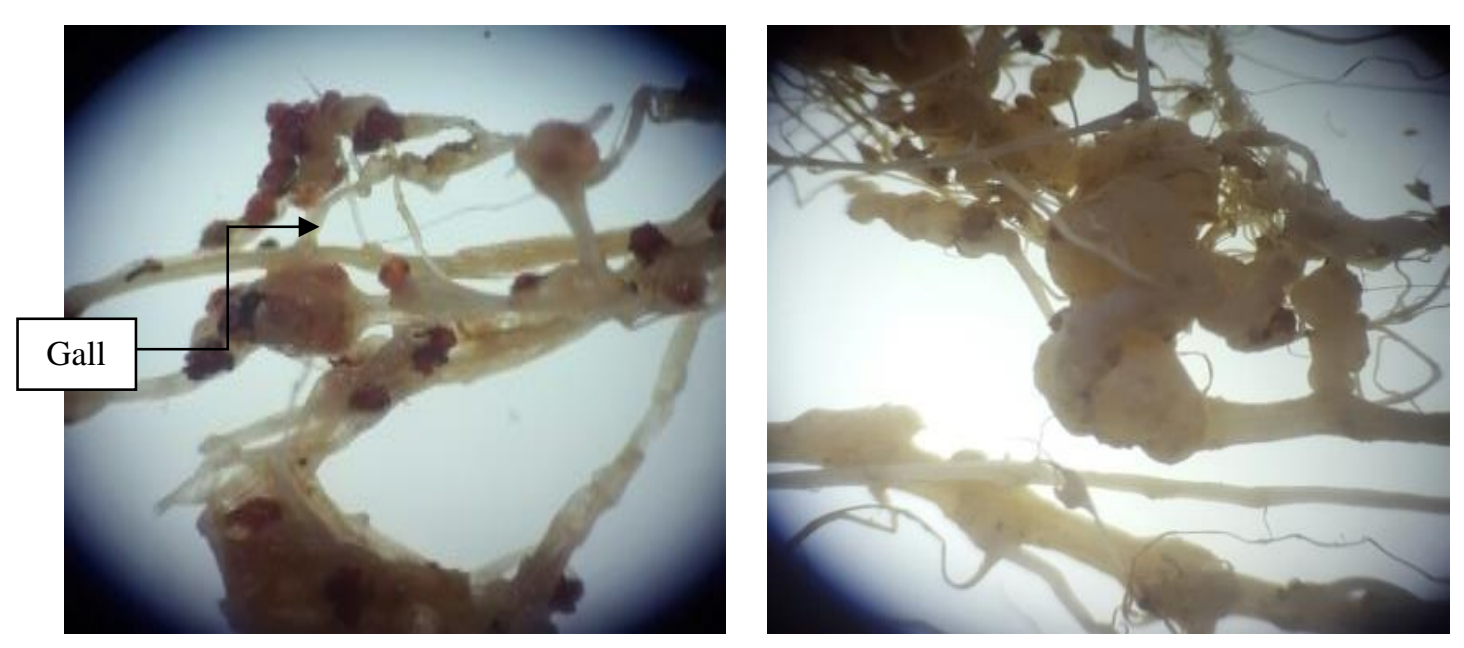

Figure 2. Effect of different inoculum levels of eggs on some infection criteria in cucumber plants. A. Signs of root-knot disease on roots. B. Symptoms of rootknot disease on roots

Table 3. Influence of different inoculum levels of M. javanica eggs on some infection criteria in cucumber plants cv.. Saffy F1.

\begin{tabular}{|c|c|c|c|c|c|c|c|c|}
\hline \multirow{2}{*}{$\begin{array}{c}\text { Treatments } \\
(\text { eggs/pot) }\end{array}$} & \multicolumn{9}{|c|}{ Infection Criteria } \\
\cline { 2 - 9 } & N.O.G. & R.G.. & N.E.M. & N/R & N/S & N.O.E. & F.P.D. & R.O.R. \\
\hline 1000 & $112 \mathrm{c}$ & $4.5 \mathrm{a}$ & $90 \mathrm{c}$ & $2017 \mathrm{e}$ & $35262.5 \mathrm{~d}$ & $30150 \mathrm{~d}$ & $67429.5 \mathrm{~d}$ & $67.4295 \mathrm{a}$ \\
\hline 2000 & $140 \mathrm{~b}$ & $5.0 \mathrm{a}$ & $93 \mathrm{c}$ & $5161 \mathrm{c}$ & $95200 \mathrm{c}$ & $31162.5 \mathrm{c}$ & $131523.5 \mathrm{c}$ & $65.7618 \mathrm{~b}$ \\
\hline 4000 & $224 \mathrm{a}$ & $5.0 \mathrm{a}$ & $128 \mathrm{~b}$ & $7113.5 \mathrm{~b}$ & $110337.5 \mathrm{~b}$ & $64312.5 \mathrm{~b}$ & $181763.5 \mathrm{~b}$ & $45.4409 \mathrm{c}$ \\
\hline 8000 & $241 \mathrm{a}$ & $5.0 \mathrm{a}$ & $140 \mathrm{a}$ & $7727 \mathrm{a}$ & $142362.5 \mathrm{a}$ & $65362.5 \mathrm{a}$ & $215452 \mathrm{a}$ & $26.9315 \mathrm{~d}$ \\
\hline 16000 & $97 \mathrm{c}$ & $4.5 \mathrm{a}$ & $78 \mathrm{~d}$ & $3042.5 \mathrm{~d}$ & $29225 \mathrm{e}$ & $23287.5 \mathrm{e}$ & $55555 \mathrm{e}$ & $3.4722 \mathrm{e}$ \\
\hline $\begin{array}{c}\text { Control (without } \\
\text { soil infestation) }\end{array}$ & $0 \mathrm{~d}$ & $0 \mathrm{~b}$ & $0 \mathrm{e}$ & $0 \mathrm{f}$ & $0 \mathrm{f}$ & $0 \mathrm{f}$ & $0 \mathrm{f}$ & $0 \mathrm{f}$ \\
\hline
\end{tabular}

- Means with different letter( s) are significantly differ depending on Duncan's Multiple Range test $(\mathrm{P} \leq 0.05)$

- Each number is a mean of 4 replications.

-N.O.G. $=$ Number of galls, R.G.I. $=$ Root gall index, N.E.M. $=$ Number of egg masses, N/R $=$ Number of nematodes/roots system,

$\mathrm{N} / \mathrm{S}=$ number of nematodes/soil pot, N.O.E. = number of eggs, F.P.D.= Final population density of nematode, R.O.R.= Rate of reproduction

\section{DISCUSSION}

These results showed that increasing in inoculum levels of nematode affected negatively on the growth criteria of cucumber plants which consistent with those cited by Al-Sabie and Ami, (1989); Kankam and Adomako, (2014) and Charegani et al. (2012) where root-knot nematodes cause reduction in growth criteria by consumption of food and energy necessary 
for normal growth of the plant, as also observed by Anwar (1995) and McClure (1977). Nematodes in infected sites disrupt the vascular region of root system and retard transmission of nutrients and water to other parts of the host plant (Hajera et al., 2009) in addition to that nematode injury restricted the growth of cucumber root system and reduced the absorption of water and nutrient by the roots (Anwar and Din, 1986; Karssen and Moens, 2006) leading to stunting of the plants as well as increased respiratory rate in infected tissue that led to the imbalance between the processes of catabolism and anabolism of the plant which in turn caused a decrease in plant height and this view is consistent with what have been mentioned by Paez et al. (1976). On the other hand root-knot nematodes destroyed root tissues, including epidermis, cortex, endodermis and pericycle during its penetration toward vascular cylinder, where females stabilized there causing formation of giant cells then malformation of vascular cylinder followed by obstruction of water and nutrient transmission to shoot system, causing a decrease in plant growth criteria, this finding is consistent with what have been indicated by Azam et al. (2010).

The translocation rate, photosynthesis and absorption decreased in infected plant by increasing the infestation levels of nematode and photosynthetic product move to root tissues, including giant cells, which developed by plant parasitic nematode infection and maintain the reproduction and development of nematode (Sharma and Sharma, 2015). The invasion of nematode reduces the ability of the plant root epidermis to take up water with pruning of root hairs and reducing root length and their branches. Damaged roots by nematode do not utilize water or fertilizers as effectively, causing additional damages for the farmers (Anwar and McKenry, 2012). The waste and toxic enzymes that put down by nematodes in the roots had a negative impact on plant growth and this effect increases with increasing the number of nematodes in the roots (Al-Sabie and Ami, 1989). In addition to the deterioration of root portability in the absorption process and moving elements to shoot system accompanied by morphological and physiological changes which adversely affect the growth and weight of root growth and other criteria (Golden and Van Gundy, 1975). It is obvious that the decrease of the root and shoot length led to decrease of their dry weight (Malekeberhan et al., 1985).

Feeding activities of nematodes interfere with plant physiological functions including photosynthesis and leading to a decline in growth criteria (Carneiro et al., 2002). The role of increasing level of nematode inoculum has been related to an increase in the formation of galls (Carneiro et al., 1999; Abrao and Mazzafera, 2001). The root gall severity increase with increasing the inoculum levels of nematode which has also recorded by Maleita et al. (2012). Nematode population density increased in the soil by increasing the level of infestation as reported by Sarmah and Sinha, (1995). The number of root galls and egg masses increased with increasing number of nematodes that entered the roots (increase the level of infestation) where increased competition for space and food (Sumita, 2014) and reduce the efficiency of females in egg production at the highest level of infestation, also due to an increase in the number of males in the root to be another reason in decreasing the amount of food (David and Triantaphyllou, 1967). Regarding nematode rate of reproduction, which decreased with increasing of inoculum levels is attributed to competition of root-knot nematode in space, food and penetration (Ibrahim, 2002; ElSharif et al., 2007; Joymatidevi, 2009; Kumar et al., 2011 and Charegani et al., 2012). The decreasing of reproduction rate may also be due to the deterioration of roots and failure of nematode to find new location of infection for generations (Hussain et al., 2011).

\section{CONCLUSION}

The growth criteria of cucumber plants (length, fresh and dry weight of roots and shoots) and chlorophyll content of leaves decreased with increasing of inoculum levels of nematode eggs, whereas the infection criteria increased except with level 16000 eggs / pot at which the infection criteria decreased. At the same time nematode reproduction rate decreased with increasing of nematode inoculum levels.

\section{REFERENCES}

Abrao, M.M., Mazzafera, P. (2001). Effects of low inoculum level of Meloidogyne incognita on cotton plants. Bragantia, 60,19-26.

AL-Sabie, R.F., Ami, S.N. (1989). The effect of inoculum levels of root-knot nematode Meloidogyne javanica on okra plant. Mesopotamia Journal of Agriculture, 21(3), 331-341. (In Arabic)

Anwar, S.A. (1995). Influence of Meloidogyne ingconita, Paratrichodorus minor and Pratylencus scribneri on root-shoot growth and carbohydrate partitioning in tomato. Pakistan Journal of Zoology, 27,105-113.

Anwar, S.A., Din, G.M. (1986). Nematodes: Biotic constrains to plant health. Parasitology, 3, 48-53.

Anwar, S.A., McKenry, M.V. (2012). Incidence and population density of plant-parasitic nematodes infecting vegetable crops and associated yield losses in Punjab, Pakistan. Pakistan Journal of Zoology, 44(2), 327-333.

Azam, T.H., Robab, M.I.(2010). Effect of initial inoculation of Meloidogyne javanica on growth and yield of Lagenaria siceraria. Journal of American Science, 6, 617-622.

Carneiro, R.G., Mazzafera, P., Ferraz, L.C.C.B. (1999). Carbon partitioning in soybean infected with Meloidogyne incognita and M. javanica. Journal of Nematology, 31,348-355.

Carneiro, R.G., Mazzafera, P., Ferraz, L.C.C.B., Muraoka, T., Trivelin, P.C.O. (2002). Uptake and translocation of nitrogen, phosphorus and calcium in soybean infected with Meloidogyne incognita and M. javanica. Fitopatol. Bras., 27:141-150.

Charegani, H., Majzoob, S., Hamzehzarghani, H., Karegar-Bide, A. (2012). Effect of various initial population densities of two species of Meloidogyne on growth of tomato and cucumber in greenhouse. Nematologia Mediterranea, 40(2), 129-134.

Coyne, D.L., Nicol, J.M., Claudius-Cole, B. (2007). Practical plant nematology: a field and laboratory guide. International Institute of Tropical Agriculture (IITA).

David, R.G., Triantaphyllau A.C. (1967). Influence of the environment on development and sex differentiation of root-knot nematode 1-Effect of infection age of The host plant and Soil temperature. Nematologica, 13, 102-110.

El-Sharif, A.G., Refaei, A.R., El-Ntagar, M.E., Salem, M.M. (2007). The role of eggs inoculum level of Meloidogyne incognita on their reproduction and host reaction. African Journal of Agricultural Research, 2(4), 159163. 
Golden, J.K., Van Gundy, S.D. (1975). A disease complex of okra and tomato involving the nematode Meloidogyne incognita and the soil-inhabiting fungus Rhizoctonia solani. Phytopathology, 65, 265-273.

Hajera, H., Feroza, N., Shahina, F. (2009). Effect of vam and nematode interaction on some biochemical parameters of sunflower. Pakistan Journal of Nematology, 27, 193-201.

Hussain, M.A., Mukhtar, T., Kayani, M.Z. (2011). Assessment of the damage caused by Meloidogyne incognita on okra (Abelmoschus esculentus). The Journal of Animal and plant Sciences, 21(4), 857-861.

Ibrahim, A.A. (2002). Effect of initial population densities of Meloidogyne javanica on tomato growth and nematode reproduction. Alex. Journal Agricuture Research, 47(2),181-189.

Joymatidevi, L. (2009). Pathogenicity of root-knot nematode, M. incognita on two different indigenous plants of Manipur. Indian Journal of Nematology, 39(1), 122-125.

Kankam, F., Adomako, J. (2014). Influence of inoculum levels of root knot nematodes (Meloidogyne spp.) on tomato (Solanum lycopersicum L.). Asian Journal of Agriculture and Food Science, 2(2),171-178.

Karssen, G., Moens, M. (2006). Root-knot nematodes. In: Plant Nematology Perry R.N., Moens, M. (eds.) CABI Publishing, Wallingford, UK, pp.5990.

Khalil, M.S. (2013). The potential of five eco-biorational products on the reproduction of root-knot nematode and plant growth. International Journal of Phytopathology, 2(2), 84-91.

Kumar, N., Adamu, M.A., Isah, K.M., Lawal, A.F. (2014). A Survey of vegetable fields for root-gall disease in Niger State, Nigeria. PAT, 10(1), 17-27.

Kumar, V., Singh, H.S., Singh, R.V. (2011). Effect on pathogenic potential and population growth of $M$. incognita race-1 on Cowpea (Vigna ununguiculata L.). Ann. Pl. Protec. Sci., 19(2), 428-432.

Maleita, C.M.N., Curtis, R.H.C., Powers, S.J., Isabel, M.D.O. (2012). Inoculum levels of Meloidogyne hispanica and M. javanica affect nematode reproduction, and growth of tomato genotypes. Phytopathologia Mediterranea, 51(3), 566-576.

Malekeberhan, H., Brooke, R.C., Wester, J.M., Dauria, J.M. (1985). Response of Phaseolus vulgaris to a single generation of Meloidogyne incognita. Nematropica, 31, 190-220.

Mcclure, M.A. (1977). Meloidogyne incognita: A metabolic sink. Journal of Nematology, 9, 88-90.

Mukhtar, T., Arshad, I., Kayani, M.Z., Hussain, M.A., Kayani, S.B., Rahoo, A.M., Ashfaq, M. (2013). Estimation of damage to okra (Abelmoschus esculentus) by root-knot disease incited by Meloidogyne incognita. Pakistan Journal of Botany, 45(3), 1023-1027.

Paez, N., Arica, M.A., Merodith, J.A. (1976). Individual and combined effect of Meloidogyne javanica on four tobacco Nicotiano tabacum cultivers in Venzeuela. Nematropica. 6(2), 68-76.

Sarmah, B., Sinha, A.K. (1995). Pathogenicity of Meloidogyne incognita on Cowpea. Plant Health. 1: 12-14.

SAS. (2001). SAS/STAT User, s Guide, Version 8.2, 1st printing.Vol.2. SAS Institute Inc, SAS Campus Drive, Gray, North Carolina.

Sharma, I.P., Sharma, A.K. (2015). Effects of initial inoculums levels of Meloidogyne incognita $\mathrm{J} 2$ on development and growth of Tomato cv. PT3 under control conditions. African Journal of Microbiology Research, 9, 1376-1380.

Stetina, S.R., Young, L.D. (2006). Comparisons of Female and Egg Assays to Identify Rotylenchulus reniformis Resistance in Cotton. Journal of nematology, 38(3), 326-332.

Sumita, K. (2014). Pathogenicity of root-knot nematode, Meloidogyne incognita in green gram. International Journal of Pure and Application Bioscience, 2(6), 182-184.

Thies, J.A., Merrill, S.B., Corley, E.L. (2002). Red food coloring stain: New, safer procedures for staining nematodes in roots and egg masses on root surfaces. Journal of Nematology, 34(2),179-181. 